\title{
Onyx for Embolization of Life-Threatening Hemoptysis: A Promising but Luxury Embolic Agent!
}

\author{
Romaric Loffroy • Sylvain Favelier • \\ Pierre-Yves Genson • Boris Guiu
}

Published online: 22 December 2011

(C) Springer Science+Business Media, LLC and the Cardiovascular and Interventional Radiological Society of Europe (CIRSE) 2011

To the Editor,

We read with great interest the article by Bommart et al. recently published in Cardiovascular and Interventional Radiology, which reported the effectiveness of selective arterial embolization using Onyx ${ }^{\circledR}$ in patients with lifethreatening hemoptysis [1]. We have several comments. Since its marketing, Onyx ${ }^{\circledR}$ has been used for the endovascular treatment of intracranial aneurysms and cerebral arteriovenous malformations [2]. Until now, few studies have examined its use for peripheral applications. Onyx ${ }^{\circledR}$ is a biocompatible polymer, which is an ethylene vinyl alcohol copolymer $(\mathrm{EVOH})$ that is dissolved in an organic solvent-dimethylsulfoxide (DMSO). It becomes radiopaque by mixing with micronized tantalum powder. When Onyx ${ }^{\circledR}$ is injected into the vessels, the DMSO rapidly diffuses, and $\mathrm{EVOH}$ solidifies at the tip of the catheter in a shape that conforms to the target area. The main advantage of Onyx ${ }^{\circledR}$ is that, unlike other liquid embolic agents, such as cyanoacrylates, it does not adhere to the endothelial wall and catheter tip, allowing better control of delivery over the embolization procedure [3].

However, Onyx ${ }^{\circledR}$ has some limitations that should be emphasized for use in interventional radiology, as previously reported [4]. First, DMSO can cause severe vasospasm, which is most likely to occur in the early phase of the procedure. This limitation may be avoided by using no more than $0.2 \mathrm{ml}$ of DMSO in the first minute of injection. Second, we find the duration of injection often time-consuming, depending of the amount of Onyx ${ }^{\circledR}$ needed. This propensity

R. Loffroy $(\bowtie) \cdot$ S. Favelier · P.-Y. Genson · B. Guiu Department of Vascular and Interventional Radiology, University of Dijon School of Medicine, Bocage Teaching Hospital, 2 Bd Marechal de Lattre de Tassigny, BP 77908, 21079 Dijon Cedex, France

e-mail: romaric.loffroy@gmail.com is confirmed by the authors who used up to $3 \mathrm{ml}$ of EVOH per patient and reported a total injection time of DMSO and Ony ${ }^{\circledR}$ up to 45 minutes for their procedure. Procedural time often is of essence when used on an emergency basis, and the use of Onyx ${ }^{\circledR}$ may lead to a loss of precious time compared with other faster embolic agents, such as glue, in such a setting. Third, DMSO is volatile and is excreted via respiration and sweat. This has a typical smell, which may last a few days. The patient should be warned to expect this. Last, Onyx ${ }^{\circledR}$ is very expensive compared with other commonly used embolic materials, and its cost increases with higher concentrations of copolymer. Its high cost explains its restricted use in neuroradiology in most of the institutions around the world and needs to be borne in mind when used in other organs. In conclusion, we think that Ony $x^{\circledR}$ is a very promising, but too luxurious, embolic agent at this time for its use in peripheral indications.

Conflict of interest None.

\section{References}

1. Bommart S, Bourdin A, Giroux MF et al (2011) Transarterial ethylene vinyl alcohol copolymer visualization and penetration after embolization of life-threatening hemoptysis: technical and clinical outcomes. Cardiovasc Interv Radiol. doi:10.1007/s00270011-0270-3

2. Panagiotopoulos V, Gizewski E, Asgari S et al (2009) Embolization of intracranial arteriovenous malformations with ethylene-vinyl alcohol copolymer (Onyx). AJNR Am J Neuroradiol 30:99-106

3. Loffroy R, Guiu B, Cercueil JP, Krausé D (2009) Endovascular therapeutic embolisation: an overview of occluding agents and their effects on embolised tissues. Curr Vasc Pharmacol 7:250-263

4. Loffroy R, Rao P, Kwak BK, Geschwind JF (2011) Superselective arterial embolisation with a liquid polyvinyl alcohol copolymer in patients with acute gastrointestinal haemorrhage [letter]. Eur Radiol 21:213 